\title{
Kendali Heading pada Trajectory Tracking Miniatur Robot Mobil
}

\author{
Farid Hasan ${ }^{1}$, Budi Bayu Murti², Fahmizal ${ }^{3}$, Muhammad Arrofiq ${ }^{4}$ \\ ${ }^{1,2,3,4}$ Departemen Teknik Elektro dan Informatika, Sekolah Vokasi, Universitas Gadjah Mada \\ farid.hasan@mail.ugm.ac.id ${ }^{1}$, budibm@ugm.ac.id ${ }^{2}$,fahmizal@ugm.ac.id ${ }^{3}$, rofiq@ugm.ac.id ${ }^{4}$
}

\begin{abstract}
This paper presents heading controls on trajectory tracking using compass sensors and global positioning sensors (GPS) on miniature robot cars. The problem that arises when the miniature robot car follows the track is the slip on the wheels. Therefore it raises heading errors that can be obtained from the compass sensor and GPS. To minimize the problems that occur, the proportional integral derivative control (PID) is applied to control the miniature headings of car robots by using the Ziegler Nichols 2nd method. In the process of finding the parameters of the PID control obtained with the results $\mathrm{Kp}=0.6 ; \mathrm{Ti}=2.5 ;$ and $\mathrm{Td}=0.625$. Furthermore, the application of the Haversine method is used to calculate the shortest distance between two points during the process of reading the position from GPS. From the test results obtained that the PID control and Haversine method are able to make the movement of a miniature robot car successfully following the test trajectory.
\end{abstract}

Keywords: Heading Control, Trajectory Tracking, Compass Sensor, GPS.

Intisari - Makalah ini menyajikan kendali heading pada trajectory tracking menggunakan sensor kompas dan global positioning sensor (GPS) pada miniatur robot mobil. Permasalahan yang timbul ketika miniatur robot mobil mengikuti lintasan ialah terjadinya slip pada roda. Oleh sebab itu menimbulkan kesalahan heading yang dapat diperoleh dari sensor kompas dan pembacaan posisi dari GPS pada miniatur robot mobil tersebut. Untuk meminimalisir permasalahan yang terjadi, kendali proporsional integral derivatif (PID) diterapkan untuk mengendalikan heading miniatur robot mobil dengan menggunakan metode ke-2 Ziegler Nichols. Dalam proses pencarian parameter dari kendali PID ini diperoleh dengan hasil $\mathrm{Kp}=\mathbf{0 . 6}$; Ti=2.5; dan $T d=0.625$. Selanjutnya, penerapan metode Haversine digunakan untuk menghitung jarak terpendek antara dua titik lintasan saat proses pembacaan posisi dari GPS. Dari hasil pengujian diperoleh bahwa kendali PID dan metode Haversine mampu membuat pergerakan miniatur robot mobil sukses mengikuti lintasan uji.

Kata kunci: Kendali Heading, Trajectory Tracking, Kendali PID, Sensor Kompas, GPS.

\section{PENDAHULUAN}

Penelitian mengenai kendaraan autonomous sudah berlangsung sejak awal tahun 1920-an dan mendapatkan momentum pada tahun 1980-an ketika para ilmuwan membuat sistem jalur bebas hambatan secara otomatis [1]. Kendaraan autonomous memberikan kepastian peningkatan pada sektor transportasi, mulai dari segi lalulintas yang lebih cepat dikarenakan respon yang lebih cepat, efisiensi bahan bakar,serta polusi yang dihasilkan lebih sedikit dan menekan angka kecelakaan dengan adanya sistem sensor dan navigasi.

Dengan berkembangnya teknologi Global Positioning System (GPS) telah memberikan banyak dampak dan kemudahan pada berbagai bidang seperti untuk proses pemetaan, navigasi (waypoint), operasi penyelamatan, militer dan pencarian rute jalan. Kendali navigasi dengan waypoint adalah algoritma navigasi yang memungkinkan sebuah objek untuk dapat bergerak secara autonomous berdasarkan masukan yang diberikan oleh sebuah operator. Referensi [2] membuat sebuah mobile robot beroda yang dapat berpindah secara otomatis dengan memanfaatkan data latitude dan longitude dari sensor GPS. Hasil penelitiannya menunjukan bahwa mobile robot dapat mencapai titik acuan yang berjarak 20 m dengan waktu 42 detik. Penelitian seragam juga dilakukan menggunakan navigasi waypoint untuk mobile robot namun dengan penambahan Global System for Mobile Communication (GSM) sebagai jembatan komunikasi antara mobile robot dengan operator [3].

Perkembangan robotika dan kecerdasan buatan (artificial intelligence) telah mendorong berbagai aspek kehidupan, salah satu diantaranya ialah perkembangan otomotif dengan lahirnya sistem self-driving car di berbagai negagra maju dan berkembang. Salah satu perusahaan yang mendorong hal tersebut dalah NVIDIA[4]. Tentunya semua kemajuan teknologi tersebut berfokus pada keamanan, kenyamanan dan efisiensi [5]. Bila mengamati kondisi negara Indonesia, jumlah kendaraan mobil di Indonesia merupakan yang terbanyak di Asia Tenggara. Hal ini akan membuat Indonesia menjadi pangsa pasar terbesar bagi perusahaan autonomous selfdriving car di masa depan. Oleh karena itu, inilah yang menjadi salah satu motivator bagi penulis untuk membuat prototipe self-driving car dengan menggunakan miniatur robot mobil yang nantinya akan menjadi cikal bakal sistem self-driving car di Indonesia. Prototipe sistem pada penelitian ini dirancang sedemikan rupa seperti pada sistem mobil sebenarnya.

Pada penelitian ini, dikembangkan kendali heading pada trajectory tracking menggunakan sensor kompas dan GPS pada miniatur robot mobil dengan model Ackerman steering. Permasalahan yang timbul ketika miniatur robot mobil mengikuti lintasan ialah terjadinya slip pada roda yang menyebabkan kesalahan heading. Sensor kompas dan pembacaan posisi dari GPS pada miniatur robot mobil digunakan untuk mengetahui kesalahan heading. Sehingga, untuk meminimalisir permasalahan yang terjadi, kendali Proportional Integral Derivative (PID) diterapkan untuk mengendalikan heading miniatur robot mobil dengan menggunakan metode ke-2 Ziegler Nichols dalam proses pencarian parameter (tuning) dari parameter kendali PID. Selanjutnya, penerapan metode Haversine digunakan untuk menghitung jarak terpendek antara dua titik lintasan saat proses pembacaan posisi dari GPS. Lebih jauh, hasil rancangan miniatur robot mobil ini merupakan sebuah prototipe dari sistem self-driving car. 
Susunan pada makalah ini disusun menjadi lima bagian. Pada bagian 2, metodologi dalam penelitian ini diusulkan. Di bagian 3 perancangan sistem kendali heading pada miniatur robot mobil dengan menggunakan kendali PID dijelaskan. Prosedur penggunaan metode ke-2 Ziegler Nichols disajikan di bagian 4 beserta eksperimen.

\section{METODE PENELITIAN}

\subsection{Ackermann Steering}

Pada penelitian ini aplikasi sistem pengemudi miniatur robot mobil menggunakan geometri kemudi Ackermann [6]. Jenis kemudi ini dirancang untuk memecahkan masalah putaran roda dalam dan luar di berbagai radius putar lingkaran saat berbelok[7]. Gambar 1 (a) merupakan ilustrasi desain dasar roda kemudi Ackermann yang sering digunakan pada kendaraan mobil. Susunan geometri Ackermann terdiri dari kingpins, steering arm, linkage pivot point, dan tie rod. Kingpins adalah ball joint yang berfungsi sebagai roda kemudi dan terhubung ke setiap roda di bagian depan. Lengan kemudi merupakan konektor dari tie rod yang juga berguna sebagai penentu perbedaan sudut putaran antara roda kanan dan roda kiri. Sedangkan linkage pivot merupakan ball joint yang berfungsi sebagai penghubung sumbu putar antara steering arm dengan tie rod.

Jika diamati pada Gambar 1 (a), kedua lengan kemudi dari roda kanan dan roda kiri akan mengarah ke tengah poros. Bagian tengah poros menentukan sudut lengan kemudi. Pengertian as roda (center of axle) adalah garis lurus yang menghubungkan roda kanan dan roda kiri. Selain itu, terdapat beberapa hal penting yang menjadi pertimbangan dalam mendesain sistem kemudi dengan Ackermaan, yang pertama adalah jarak antara roda depan dengan roda belakang atau jarak sumbu roda (wheel base). Yang kedua adalah jarak antara ball joint di roda depan kiri dan kanan. Hal lain yang tidak kalah pentingnya adalah memperhatikan posisi lengan kemudi, apakah diposisikan di depan sumbu kemudi atau di belakang poros kemudi. Berdasarkan referensi [8], kemudi Ackermann akan sangat sulit diproduksi jika penempatan lengan kemudi terletak di bagian depan, sehingga penempatan lengan kemudi akan lebih baik jika ditempatkan di belakang sumbu kemudi. atau disebut lengan kemudi belakang (rear steering arms).

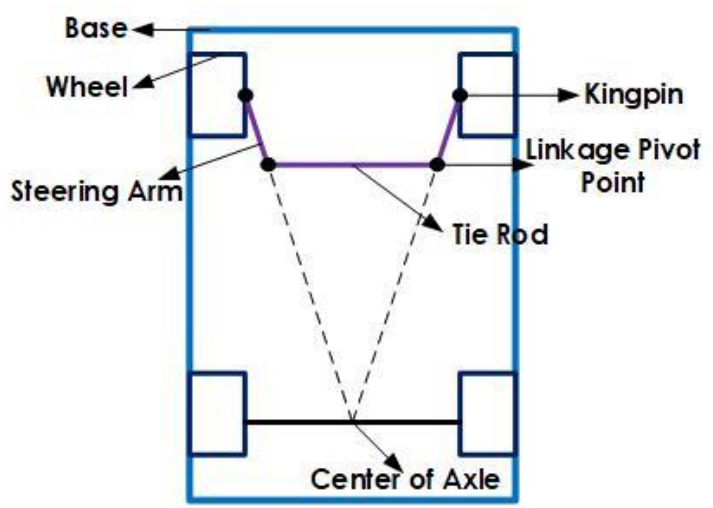

(a)

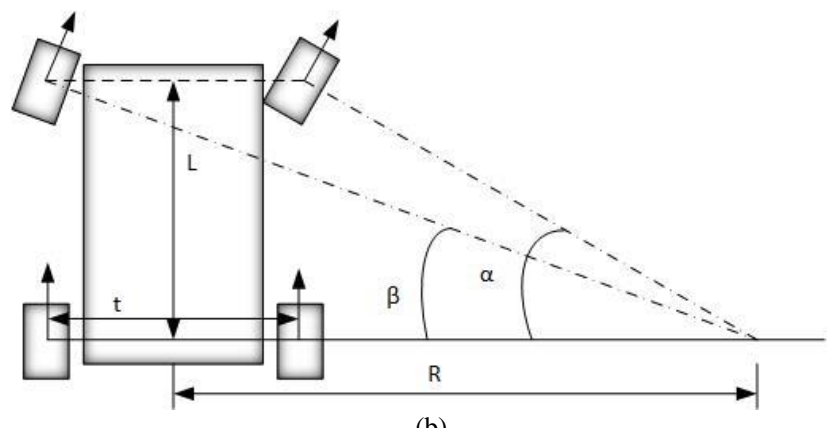

(b)

Gambar 1. (a). Ilustrasi Geometri Ackermann (b). Radius Putar pada Kemudi Ackermann

Mengacu pada Gambar 1 (b), jari-jari radius putar $(R)$ adalah jari-jari lingkaran yang dapat ditimbulkan oleh mobil saat berbelok satu kali putaran penuh ke kanan atau ke kiri. $R$ dihitung dari pusat poros sampai titik potong perpanjangan garis tegak lurus masing-masing roda. Saat berbelok, nilai sudut berbelok roda depan kanan dan kiri akan berbeda. Nilai sudut belok ini dijelaskan pada persamaan (1) yang digunakan pada saat mobil berbelok ke kiri atau berlawanan arah jarum jam (counter clock wise), sedangkan pada persamaan (2) digunakan pada saat mobil berbelok ke kanan atau searah jarum jam (clock wise).

$$
\begin{array}{ll}
\alpha_{\text {Left }}=\tan ^{-1}\left(\frac{L}{R-t / 2}\right) & \beta_{\text {Left }}=\tan ^{-1}\left(\frac{L}{R+t / 2}\right) \\
\alpha_{\text {Right }}=\tan ^{-1}\left(\frac{L}{R+t / 2}\right) & \beta_{\text {Right }}=\tan ^{-1}\left(\frac{L}{R-t / 2}\right)
\end{array}
$$

\subsection{Formula Haversine}

Kendali trajectory tracking pada penelitian ini memanfaatkan Formula Haversine yang digunakan untuk mengetahui jarak antar dua titik dengan memperhitungkan bahwa bumi adalah bukan sebuah bidang datar [9]. Kita ketahui bahwa bumi memiliki derajat kelengkungan yang dapat dicari pada persamaan (3). Formula ini pertama kali ditemukan oleh Jamez Andrew pada tahun 1805.

$$
\begin{gathered}
\Delta \text { lat }=\text { lat2 }- \text { lat1 } \\
\Delta \text { long }=\text { long2 }- \text { long1 } \\
a=\sin ^{2}(\Delta \text { lat } / 2)+ \\
\cos (\text { lat } 1) \cdot \cos (\text { lat } 2) \cdot \sin ^{2}(\Delta \text { long } / 2) \\
c=2 \operatorname{atan~} 2(\sqrt{a}, \sqrt{1-a}) \\
d=\text { R.c }
\end{gathered}
$$

keterangan:

$$
\begin{array}{ll}
\mathrm{R} & =\text { jari-jari bumi sebesar } 6371(\mathrm{~km}) \\
\Delta \text { lat } & =\text { besaran perubahan latitude } \\
\Delta \text { long } & =\text { besaran perubahan longitude } \\
\mathrm{c} & =\text { kalkulasi perpotongan sumbu } \\
\mathrm{d} & =\text { jarak }(\mathrm{km}) \\
1 \text { derajat } & =0.0174532925 \text { radian }
\end{array}
$$

\subsection{Kendali PID}

Pada penelitian ini, kendali posisi steering dari miniatur robot mobil dikendalikan dengan menggunakan kendali PID digital. Kendali ini merupakan bentuk kendali PID analog yang telah dilakukan digitalisasi. Bentuk umum dan tahapan digitalisasi kendali PID disajikan pada persamaan (4)-(6).

$$
u(t)=K_{p} e(t)+\frac{1}{\tau_{j}} \int e(t) d t+\tau_{d} \frac{d}{d t} e(t)
$$


Parameter $K i=\frac{1}{\tau_{i}}$ dan $K d=\tau_{d}$, adalah konstanta integral dan diferensial dan dalam bentuk diskrit dapat ditulis seperti pada Persamaan (5). Sehingga diperoleh kendali PID digital pada Persamaan (6).

$$
\begin{aligned}
& \int_{0}^{t} e(t) d t \approx \mathrm{T} \sum_{0}^{\mathrm{k}} \mathrm{e}(\mathrm{k}) \operatorname{dan} \frac{d e(t)}{d t} \approx \frac{e_{k}-e_{k-1}}{T} \\
& u_{(k)}=K_{p} e_{k}+K_{i} T \sum_{0}^{k} e_{k}+\frac{1}{T} K_{d}\left(e_{k}-e_{k-1}\right)
\end{aligned}
$$

\subsection{Metode ke-2 Ziegler Nichols}

Untuk mengetahui parameter konstanta kendali PID, diperlukan tuning. Pada penelitian ini menggunakan metode ke-2 dari Ziegler Nichols. Proses penyetelan pada metode ini dilakukan dengan meningkatkan parameter kendali proporsional $(\mathrm{Kp})$ yang dinaikkan nilainya dari nol menjadi nilai kritis Kp, sehingga diperoleh keluaran berosilasi yang kontinyu dengan amplitudo yang sama. Nilai kritis Kp ini dikenal sebagai ultimated gain $(\mathrm{Ku})$. Respon keluaran yang dihasilkan dalam tiga kondisi penguatan proporsional disajikan pada Gambar 2. Sistem dapat berosilasi secara stabil pada $\mathrm{Kp}=\mathrm{Ku}$.

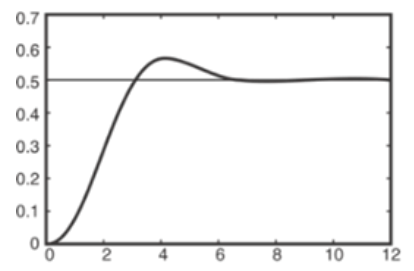

(a) Nilai $\mathrm{Kp}=1$

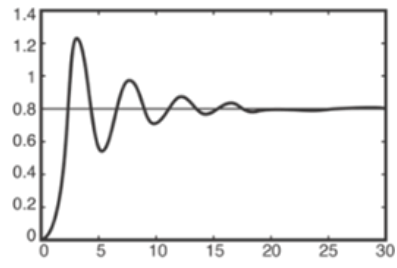

(b) Nilai $\mathrm{Kp}=1<\mathrm{Kp}<\mathrm{Ku}$

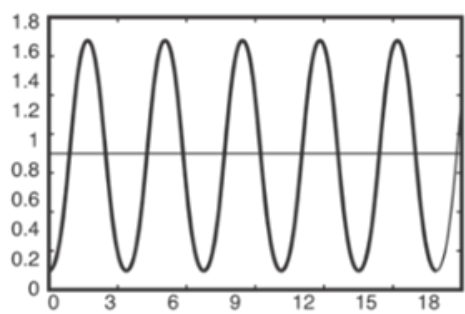

(c) Nilai $\mathrm{Kp}=\mathrm{Ku}$

Gambar 2. Karakteristik keluaran suatu sistem dengan penambahan Kp.

Selanjutnya, nilai ultimate periode, $\mathrm{Tu}$, dapat diperoleh bila respons keluaran sistem telah mencapai kondisi yang mengalami osilasi secara terus menerus. Apabila nilai Tu dan $\mathrm{Ku}$ telah didapat, maka untuk dapat menentukan konstanta-konstanta pengendali sesuai dengan tetapan empiris dari meode ke-2 Ziegler Nichols disajikan pada Tabel I [10].

TABEL I

PenalaAn ZieGler-Nichols Metode Ke-2

\begin{tabular}{|l|c|c|c|}
\hline \multicolumn{1}{|c|}{ Pengendali } & $\mathrm{Kp}$ & $\mathrm{Ti}$ & $\mathrm{Td}$ \\
\hline $\mathrm{P}$ & $0.5 * K u$ & - & - \\
\hline $\mathrm{PI}$ & $0.45 * K u$ & $\frac{1}{1.2} * T u$ & - \\
& & & \\
\hline PID & $0.6 * K u$ & $0.5 * T u$ & $0.125 * T u$ \\
\hline
\end{tabular}

\section{PERANCANGAN SISTEM}

\subsection{Sistem Mekanik dan Elektronik}

Pada penelitian ini menggunakan sebuah miniatur robot mobil yang telah dilakukan beberapa perubahan pada sistem mekanik dan elektronik nya seperti yang disajikan pada Gambar 3.a dan Tabel 2 untuk data spesifikasinya. Serta penambahan sensor feedback pada bagian steering menggunakan potensio dan gear yang dikopel dengan "as" Ackerman steering roda depan miniatur robot mobil seperti yang disajikan pada Gambar 3.b.

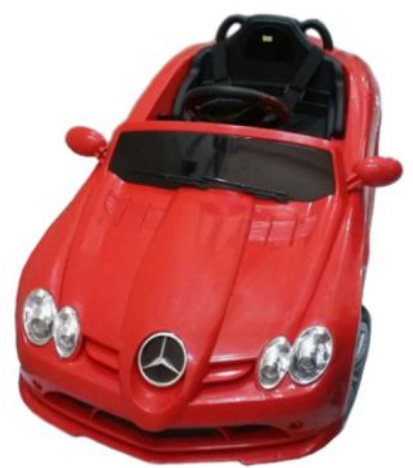

(a)

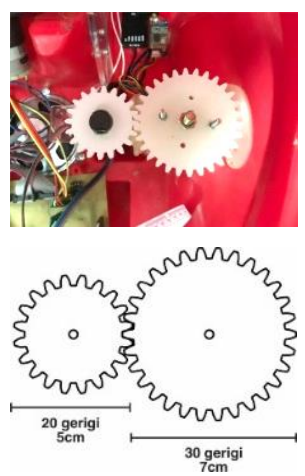

(b)
Gambar 3. (a) Miniatur Robot Mobil; (b) Sensor Feedback pada Bagian Steering Menggunakan Potensio dan Gear

TABEL II

SPESIFIKASI MINIATUR ROBOT MOBIL

\begin{tabular}{ll} 
Model & $\begin{array}{l}\text { Mercedes Mclaren SLR 722 S } \\
\text { berlisensi }\end{array}$ \\
\hline Warna yang tersedia & Merah, Putih dan Hitam \\
\hline Bahan & Plastik dengan ban roda karet \\
\hline Kecepatan & $3-5 \mathrm{~km} / \mathrm{h}$ \\
\hline $\begin{array}{l}\text { Kapasitas beban } \\
\text { maksimum }\end{array}$ & $35 \mathrm{Kg}$ \\
\hline Baterai & $12 \mathrm{V7AH}$ \\
\hline Motor & 2 Roda Belakang, 1 Steering \\
\hline Dimensi & $120 \mathrm{~cm}$ x 56cm x 45cm \\
\hline Sertifikasi & Rohs, EN71, EN62115, ASTM, CE \\
\hline Model & $\begin{array}{l}\text { Mercedes Mclaren SLR 722 S } \\
\text { berlisensi }\end{array}$
\end{tabular}

Pada bagian elektronika terdiri dari perangkat berupa sensor yang terdiri atas kompas dan GPS, perangkat embeded microncontroler menggunakan Arduino Mega dan tiga buah driver motor sebagai actuator pergerakan. Diagram blok dari sistem elektronika disajikan pada Gambar 4. 


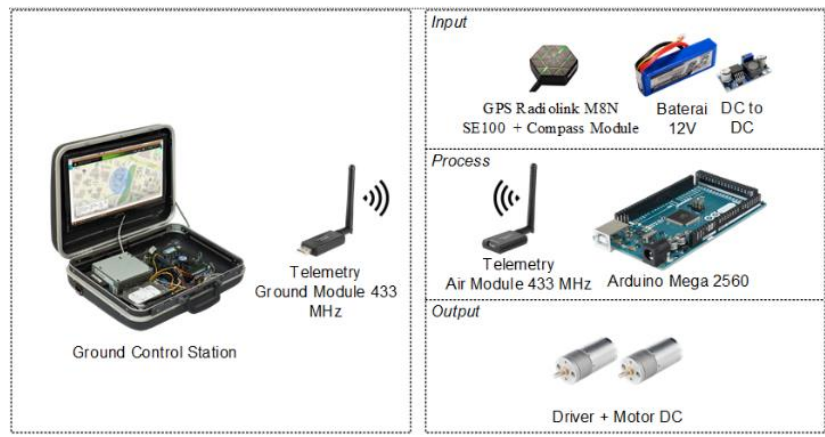

Gambar 4. Diagram Blok dari Sistem Elektronika Miniatur Robot Mobil

\subsection{Sistem Kendali Heading}

Pada penelitian ini, kendali heading menggunakan kendali PID digital. Diawali dengan membuat dua buah variable berupa error dan last error. Kedua variable tersebut digunakan pada perhitungan aksi kendali PID. Nilai variable error diperoleh dari hasil pengurangan antara setpoint dengan hasil pembacaan sensor sudut pada steering miniatur robot mobil. Dan data variable last error meupakam nilai error sebelumnya. Terdapat dua loop perhitungan kendali PID pada penelitian ini. Yang pertama digunakan untuk mengatur kecepatan roda belakang dari miniatur robot mobil seperti yang disajikan pada Gambar 5 dan mengatur sudut steering roda depan miniatur robot mobil seperti pada Gambar 6.

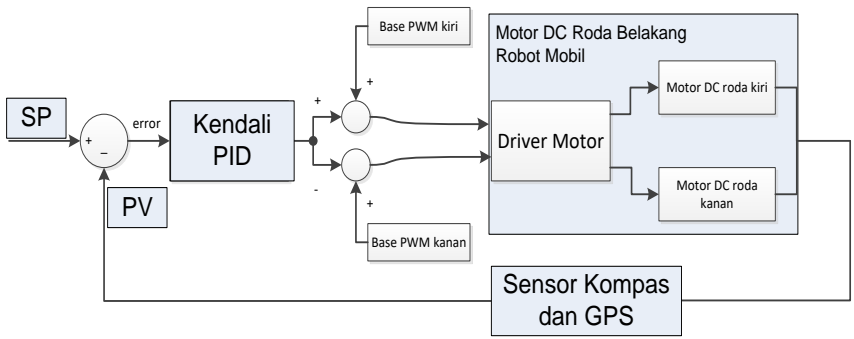

Gambar 5. Blok sistem kendali PID dalam mengatur kecepatan roda belakang dari miniatur robot mobil

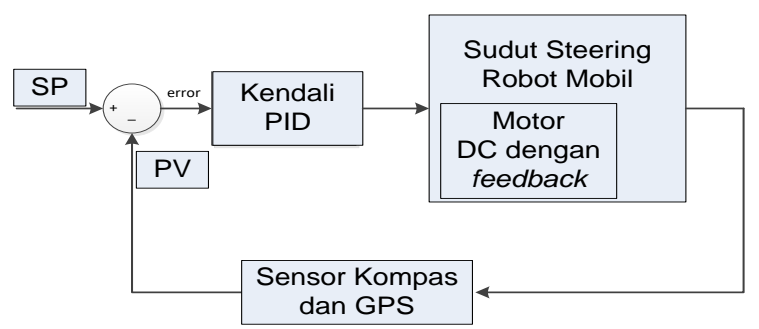

Gambar 6. Blok sistem kendali PID dalam mengatur sudut steering roda depan dari miniatur robot mobil

Selanjutnya perancangan Graphical User Interface (GUI) juga sangat diperlukan untuk memonitoring keadaan miniatur robot mobil secara realtime. Pada penelitian ini dikembangkan sebuah GUI untuk memonitor trajectoy tracking dari miniatur robot mobil yang dirancang menggunakan aplikasi Processing IDE seperti yang ditunjukkan pada Gambar 7.

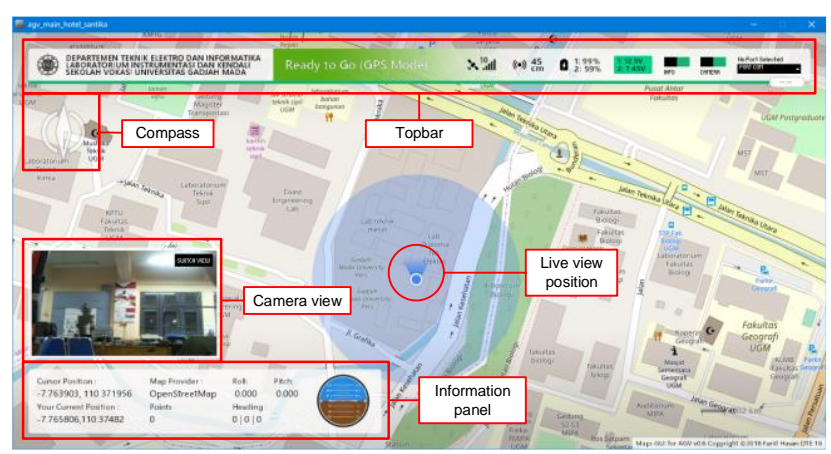

Gambar 7. Tampilan GUI untuk memonitor trajectroy tracking dari miniatur robot mobil

\section{HASIL DAN PEMBAHASAN}

\subsection{Pengujian Kendali Heading}

Langkah pertama ialah dengan menguji radius putar dari miniatur robot mobil dengan hasil seperti pada Gambar 8.a dengan cara memberi sudut maksimal dari steering miniatur robot mobil sebesar 35 derajat seperti yang disajikan pada Gambar 8.b. Selanjutnya dilakukan inisialisasi kondisi derajat heading error dan penentuan arah berbelok miniatur robot mobil seperti yang disajikan pada Gambar 8.c.
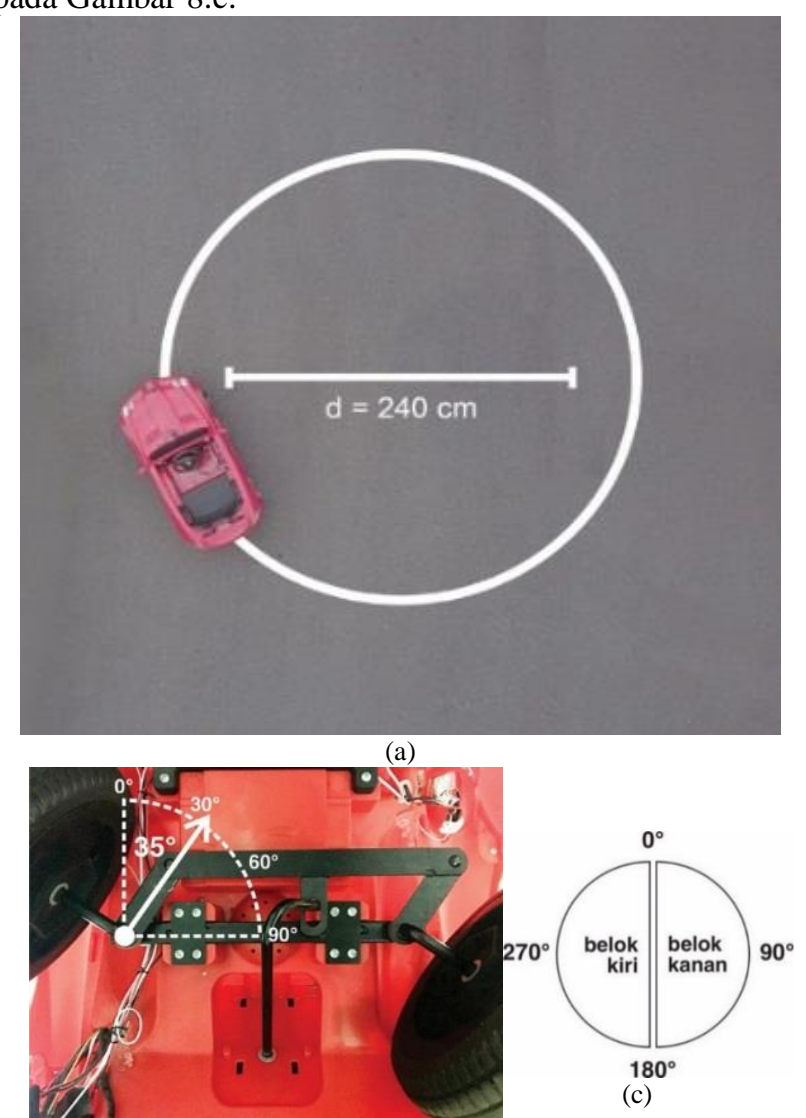

(b)

Gambar 8. Pengujian radius putar miniatur robot mobil dengan steering sebesar 35 derajat dan penentuan arah belok berdasarkan derajat heading error

Setelah itu dilakukan tuning kendali PID pada steering miniatur robot mobil menggunakan metode Ziegler Nichols ke-2. Langkah awal ialah dengan cara membuat sistem steering miniatur robot mobil ini mengalami osilasi seperti yang disajikan pada Gambar 9.a adalah data pembacaan potensio pada feedback steering dari miniatur robot mobil. 
Bila dilakukan normalisasi data diperoleh nilai tengah dari sudut steering (0 derajat) adalah 450. Nilai gain ultimate (Ku) diperoleh sebesar 10 telah membuat sistem steering miniatur robot mobil ini mengalami osilasi yang terus menerus dengan teratur. Langkah selanjutnya ialah mencari periode ultimate $(\mathrm{Tu})$ seperti yang disajikan pada Gambar 9.b diketahui Tu sebesar 5 detik.

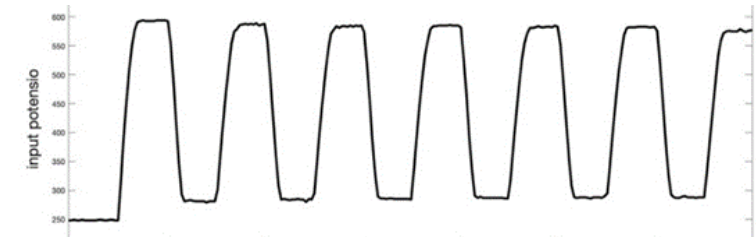

(a)

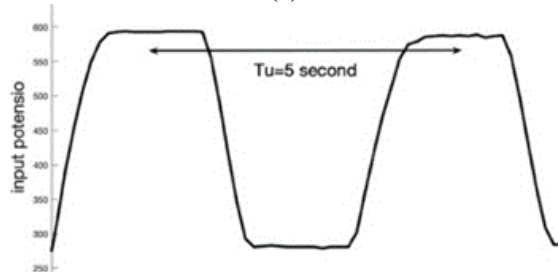

(b)

Gambar 9. (a) Osilasi teratur ketika gain ultimate diberi nilai 10; (b) Nilai periode ultimate sebesar 5 detik

Dengan mengacu pada tetapan empiris metode ke-2 Ziegler-Nichols seperti pada Tabel 1 diperoleh masing parameter kendali PID menjadi berikut, $\mathrm{Kp}=0.6 * 10=6$; $\mathrm{Ti}$ $=0.5 * 5=2.5$; dan $\mathrm{Td}=0.125 * 5=0.625$.

\subsection{Pengujian Trajectory Tracking}

Pengujian berikutnya adalah dengan memberikan titik point lintasan yang harus dilalui miniatur robot mobil. Titik-titik lintasan ini berupa koordinat latitude dan longitude yang diperoleh dari Google maps pada GUI. Selanjutnya data sensor GPS yang berada pada miniatur robot mobil diolah dengan metode Haversine untuk dicari jarak antar dua titik tersebut dan arah heading dari miniatur robot mobil. Titik-titik lintasan tersebut disajikan seperti pada Gambar 10.a. Hasil rekaman trajectory tracking dari miniatur robot mobil yang ditangkap melalui citra udara dari ketinggian 90-meter ditunjukkan pada Gambar 10.b dan telah disimpan pada channel video YouTube di link https://youtu.be/kiDGoK4uaWI.

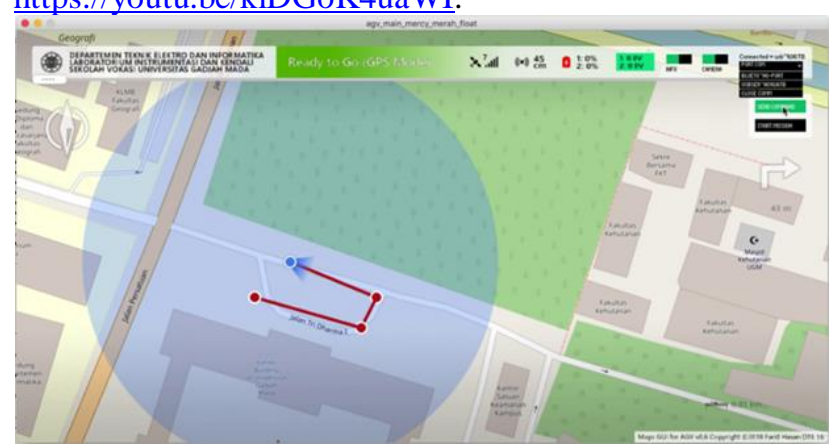

(a)

ISSN : $2746-2536$

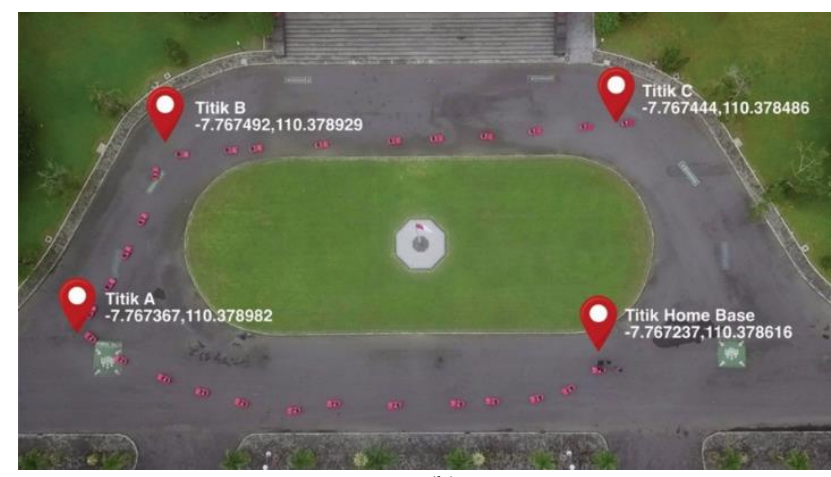

(b)

Gambar 10. (a) Titik-titik lintasan latitude dan longitude; (b) Hasil rekaman trajectory tracking dari miniatur robot mobil yang ditangkap melalui citra udara dari ketinggian 90 meter

\section{KESIMPULAN}

Penerapan kendali PID pada heading miniatur robot mobil telah membuat pergerakan menjadi lebih stabil dan mampu bermanuver secara aman, halus, responsif dan cepat. Dengan metode ke-2 Ziegler-Nichols diperoleh parameter kendali PID dengan hasil $\mathrm{Kp}=0.6$; $\mathrm{Ti}=2.5$; dan $\mathrm{Td}=0.625$ untuk mengendalikan steering motor DC miniatur robot mobil pada bagian roda depan. Selanjutnya, untuk riset yang akan datang, diharapkan adanya pengembangan metode kendali dengan menggunakan kendali cerdas seperti logika fuzzy.

\section{UCAPAN TERIMA KASIH}

Penulis mengucapkan terima kasih kepada Sekolah Vokasi UGM pada skema hibah penelitian kompetitif tahun 2019.

\section{DAFTAR PUSTAKA}

[1] Bagloee, S. A., Tavana, M., Asadi, M., \& Oliver, T., Autonomous vehicles: challenges, opportunities, and future implications for transportation policies, Journal of modern transportation, vol.24(4), p.p. 284-303, 2016.

[2] Prakoso, R., Pangaribuan, P., \& Wibowo, A. S., Perancangan sistem kendali mobile robot dengan GPS menggunakan metode PID, eProceedings of Engineering, vol. 5(3), 2018.

[3] Khan, S., Ahmad, K., Murad, M., \& Khan, I., Waypoint navigation system implementation via a mobile robot using Global Positioning System (GPS) and Global System for Mobile Communications (GSM) modems, International Journal of Computational Engineering Research (IJCER),2013.

[4] Bojarski, M., Del Testa, D., Dworakowski, D., Firner, B., Flepp, B. Goyal, P., \& Zhang, X., End to End Learning for Self-Driving Cars, arXiv preprint, arXiv:1604.07316, 2016.

[5] Maślak, W., \& Butkiewicz, B. S., Autonomous vehicle with fuzzy control, In Signal Processing Symposium (SPS), IEEE, p.p.1-6, 2013.

[6] Hunt, K. H., Kinematic Geometry of Mechanisms, Oxford University Press, USA, 1978, vol. 7.

[7] Angeles, J., Fundamentals of Robotic Mechanical Systems, New York: Springer-Verlag, 2002, Vol. 2.

[8] Fahmizal, Murti, B. B., Pratama, D. B., \& Mayub, Kendali logika fuzzy pada Car Like Mobile Robot (CLMR) penjejak garis, ELKOMIKA: Jurnal Teknik Energi Elektrik, Teknik Telekomunikasi, \& Teknik Elektronika, vol.6(3), p.451, 2018.

[9] Yulianto, R., \& Kridalaksana, A. H., Penerapan formula Haversine pada Sistem Informasi Geografis pencarian jarak terdekat lokas lapangan futsal, Jurnal Ilmiah Ilmu Komputer, vol. 13(1), p.p.14$21,2018$.

[10] Ogata, K., Modern Control Engineering, Upper Saddle River, p.p. 6142-6143, Prentice Hall, NJ, 2009 